
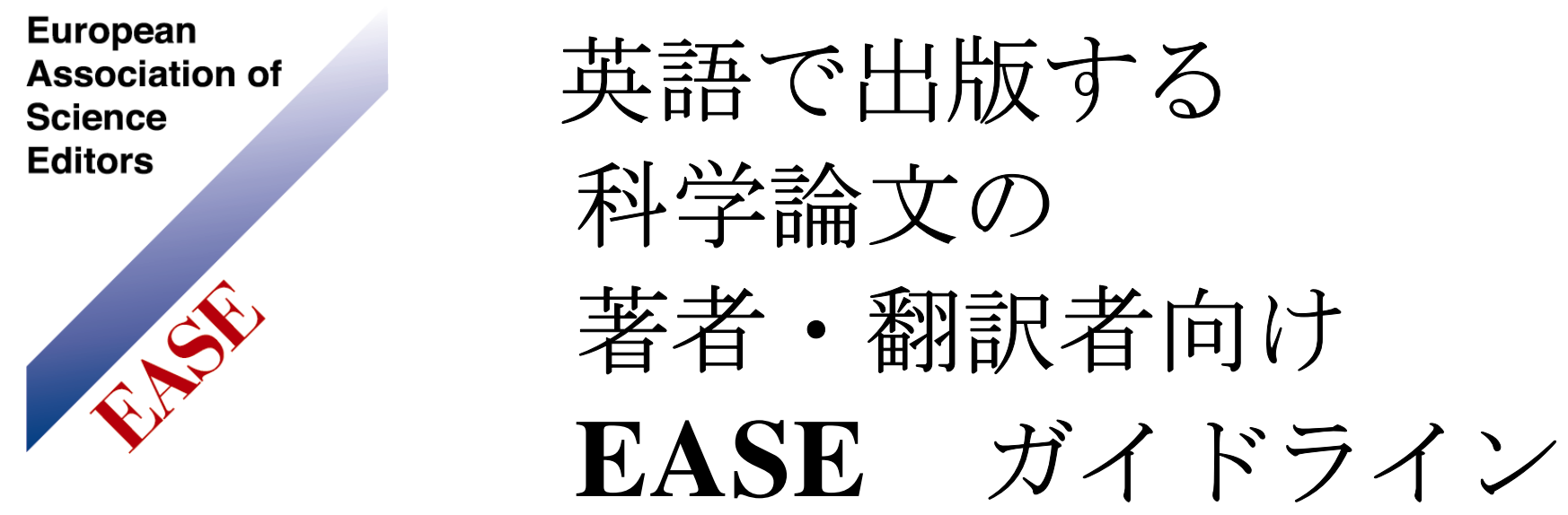

要約

欧州科学編集者協会 (European Association of Science Editors : EASE) は、本編集ガイドラインを 2010 年に 発表以来、簡潔で読みやすいを目標に年次更新してい ます。 http://ease.org.uk/publications/author-guidelines で 20 ケ国語にて無料で提供しています。世界中の科学 者向けに、研究結果の発表サポートや、母国語ではな く英語で正確に執筆するためのサポートを目指してい ます。完全かつ簡潔、明確な論文の執筆方法を分かり やすく説明し、また、オーサーシップの基準、剽窃、 利益相反等の倫理問題にも注意を促しています。8つ の付録 Abstracts、Ambiguity、Cohesion、Ethics、 Plurals、Simplicity、Spelling、Text-tables では、例文 や特定のトピックについてのより細い情報を載せてい ます。本 EASE Guidelines を十分にご活用いただき、国 際的な科学コミュニケーションの効率向上につながれ ばと願っています。

国際的な科学コミュニケーションをより効果的 にするために、研究論文やその他科学系出版物 は以下で説明するように、完全かつ簡潔、明快 であるべきです。著者および翻訳者、編集者の サポートを目的とした本ガイドラインは、一般 的な指針を示していますが、絶対的なものでは ありません。完全なものではないので、常識を 持って対応しましょう。

書き始める前に :

・綿密な計画を立てて研究を実施する（例： Hengl et al 2011）。信頼性のある結論を出すた めに、研究結果が確実かつ完全であると確信 するまで論文を書き始めない（ O'Connor 1991）。

・書き始める前にジャーナルを選択することが 望ましい。ジャーナルの読者層と自分が対象 とする読者層が一致しているかを確認する

（Chipperfield et al 2010）。ジャーナルの投稿規程 を入手し、全体の長さや、図表の必要数または 許容数等に関して、ジャーナルが望むフォーマ ットにそって論文作成計画を立てる。

論文は完全でなければなりません。つまり、必 要な情報が欠如していてはなりません。情報は 読者が「ここに書いてあるだろうと」推測しや すい場所にあれば、より理解が深まることを覚 えておきましょう（Gopen \& Swan 1990）。例えば、 実験的研究論文には以下の情報を含むべきです。

-タイトル：他分野の専門家にも明確かつ理解で きるものであり、さらに論文の内容を反映した ものであること。具体的であり、一般的または 曖昧ではないこと（O'Connor 1991）。関係があ れば、タイトルに研究期間や場所、研究対象と なった有機体の国際的な学名、実験計画（例： ケーススタディ、ランダム化比較試験）を含め る。ヒトの一方の性を対象にした研究の場合は、 その旨をタイトルに含める。重複する場合はや むを得ないが、タイトルに含める情報はアブス トラクトの中で繰り返す必要はない（常に併記 されるため）。

・著者一覧 : 著者とは、研究計画やデータ収集、 結果の解釈に大いに貢献した、かつ論文を執筆 または大幅な見直しを行った、および決定稿を 承認し、さらに研究に関するあらゆる責任を持 つことに同意した者であり、著者一覧にはこれ らの者を記載する。データ収集や結果の解釈に 貢献した者は論文の執筆および決定稿の承認に 関与が許されるべきである（ICMJE 2015）。最 も貢献した者を著者一覧の最初に示す。著者名 の順番は、論文投稿前に決定しておくこと。投 稿後の論文にいかなる変更を加える場合も著者 
全員の承認を得て、またジャーナル編集長に 説明をすること。著者名欄には、著者の（研 究中の）所属、現住所を連絡用に記載するこ と。連絡が付きやすいように著者全員のメー ルアドレスも記載しておくこと（Battisti et al 2015, COPE flowcharts 参照）。

・アブストラクト：研究を行った理由 （BACKGROUND）、何の疑問に答えようとし ているのか（OBJECTIVES）、どのように研究 を行ったか（METHODS）、発見事項

（RESULTS：主なデータ、関連性）、発見に 対する解釈と主な帰結（CONCLUSIONS）を簡 潔に説明すること。大半の読者にとって、ア ブストラクトは研究に関する主な情報源とな るので、論文の内容を反映させる。研究結果 に興味を持ちそうな人に、論文がオンライン で検索されやすいように、あらゆるキーワー ドをアブストラクトに含める（データーベー スの多くはタイトルとアブストラクトしか含 んでいない）。研究レポートにおいては、ア ブストラクトは実際の結論を含む有益な情報 であること（構造化アブストラクトについて は Appendix: Abstracts 参照）。査読、メタ分析、 その他広範囲な論文においてのみ、アブスト ラクトは指標となるものであること。例えば、 主な論点は列挙するが結果は示さない（CSE 2014）。アブストラクトは別に掲載されるの で、アブストラクトの中では図表を参照しな いこと。文献参照は、どうしても必要である 場合を除き許されていない（但し、括弧の中 で著者やタイトル、年数等の詳細情報を示す 必要がある）。アブストラクトにある情報は 全て、論文本文中にも必ず登場していること。

・キーワードリスト：タイトルに含まれていな い全ての関連科学用語や追加のキーワードの みを列挙する（ジャーナル編集長が要求する 場合）。固有のキーワードであること。研究 が学際的な意味合いをもつ場合は、より一般 的な用語を追加すること（O'Connor 1991）。 メディカル文書では、MeSH Browser にある語 彙を使用する。論文をリポジトリにアーカイ ブ等する場合（Cerejo 2013）は、全てのキーワ 一ドやその他メタデータをファイルに埋め込 む（Inderscience 2013 参照）

・略語リスト（ジャーナル編集長が要求する場 合）: 専門家以外の人たちに対しても明白で あるという場合を除き、論文で使用する略語 は全て定義すること。
- 序文 : 研究の必要性を説明し、研究目的や何の 疑問に答えようとしているのかを明確にする。 より一般的な問題から始め、徐々に研究課題に 焦点を当てていく。

- 方法 : 研究の実施方法を詳細に説明する（例： 研究範囲、データ収集、基準、分析物質の出所、 サンプルの規模、計測数、参加者または組織・ 細胞提供者の年齢・性別、装置、データ分析、 統計的検定、使用ソフトウェア）。結果に影響 しうる全ての要因を考慮する必要がある。バイ オバンクから実験材料を入手した場合は、可能 であれば、正式名称および識別子を示す

（Bravo et al 2015）。英語以外またはアクセスで きない出版物に記載されている方法を引用する 場合は、論文の中で詳細に説明する。患者の権 利や動物実験、環境保護等については、倫理規 範（例：WMA 2013）を必ず遵守すること。

- 結果 : 研究の新しい結果を示す（通常、公表済 みデータは本項には含むべきではない）。図表 は全て論文記載順に番号を付加し、論文本文に 記述すること。統計解析は必ず適切であること

（例：Lang 2004）。ヒト、動物、またはヒトや 動物から採取した組織に関するデータは、性別 で分類する（Heidari et al 2016 参照）。データの 加工や歪曲、重要なデータを排除してはならな い。また、読者の誤解を招くような困を作成し てはならない。データ改ざんは科学的不正行為 になる可能性がある（COPE flowcharts 参照）。

- 考察 : 統計結果を含め、新しい結果を示すセク ションではない。（序文の終わりに記載した） 研究課題に回答し、できるだけ客観的に新しい 結果と公表済みデータを比較する。研究の欠点 や主な結果を考察する。一方の性のみを対象と して研究した場合は、両性への研究結果の影響 や一般化可能性を考察する。自分の考えに反す る結果も全て考慮する。見解を立証するために、 秩序立った信頼できる証拠を使用する（Roig 2011）。考察の最後または別の項で研究の主な 結論や実際的意義を強調する。

- 謝辞：共同著者を除く研究に大いに貢献した 人々について言及し、あらゆる資金源へ感謝を 示す。“This work was supported by the Medical Research Council [grant number xxxx]”の形式を推奨 する。特定の資金源が無い場合は次の文書を 記載する。“This research received no specific grant from any funding agency in the public, commercial, or not-for-profit sectors.”（RIN 2008）その他に利益相 反があれば編集者に公表する。例えば、メーカ 
一または投稿論文に興味がある組織との金銭 的、個人的関係等（Goozner et al 2009）。発表 済みの図表等を利用する場合は、著作権所有 者に確認し、図表の説明文か謝辞の中で言及 する。言葉の専門家（例：校正者、翻訳者） や統計学者、データ収集者等にサポートして もらった場合は、透明性を確保するために彼 らのサポートに対して謝辞を述べる（ICMJE 2015, Battisti et al 2015）。但し論文の決定稿に 対する責任はないことを説明する。謝辞に挙 げた人全ての同意を必ず得ること（Appendix: Ethics 参照）。

- 参照：その他出版物から引用した情報は情報 源を全て必ず明らかにする。参照リストには、 図書館やインターネットで検索する際に必要 なデータを全て含むこと。非英語出版物につ いては可能な限り大括弧の中に（必要ならば 英語表記に従って音訳された）原題を記載す ること（CSE 2014）。アクセスできないデータ の引用や、強制的または無関係な引用は避け る。適宜、総説ではなく原著論文を引用する （DORA 2013）。参照リストに非公表のデータ は含めない。非公表データを記載する場合は、 論文本文に情報源を記載する。データを引用 する際には生産者から許可を得ること。

・理論に関する出版物や総説、ケーススタディ 等には異なる論文の構造が適切な場合もある （例：Gasparyan et al 2011）。

・出版物の中には、アブストラクトや長めの概 要がその他の言語で記載されている場合もあ る。これは多くの研究分野において非常に有 益である。

・レポートガイドラインは、研究に関する必要 最低限の情報を提供している（例：EQUATOR Network）。

•アブストラクトの長さや参照スタイル等につ いては、ジャーナルの投稿規定に従うように 留意する。

\section{査読者と読者の時間を節約するために「簡潔」 に記述する}

- 序文に示した研究課題に無関係な情報は含め ない。

・自分が過去に発表した論文を丸写しせず、ま た同じ論文を 2 つのジャーナルに同時に投稿 しないこと。さもなければ、二重投稿になる 可能性がある（COPE flowcharts 参照）。これ
は、会議アブストラクトのような予備的出版に は適用されない（O’Connor 1991、参照 BioMed Central policy）。また、完全に異なる読者層

(例：別言語、専門家および一般大衆への出 版）に対する場合、および両ジャーナルのジャ 一ナル編集長から許可を得た場合は、第二次的 出版が認められる（ICMJE 2015）。二次出版の タイトルページ脚注に一次出版について言及す ること。

- ある箇所に記載される情報を、別の箇所で繰り 返し記載しないほうが良い。アブストラクト、 困表の凡例、結論を示す項は除く。

- 図表全ての必要性を検討する。表に示すデータ は図で再度示すべきではない（逆も同様）。デ ータのリストが長い場合は、文書中に繰り返す べきではない。

-図表に対する説明は、参考情報とし長くなりす ぎないこと。類似データが複数の図表に示され ている場合は、説明形式も同様にすべきである

- 疑う余地の無い説明（例：“Forests are very important ecosystems.”）、その他圥長表現（例 : “It is well known that...”) は削除するのが望まし い。

・長い科学用語を繰り返し使用する場合は、論文 本文の中での初回言及時に略語を定義し、その 後はその略語を使用する。

・必要であれば懸念事項を示すが、過度に言葉を 濁すのは避ける（例：“may possibly be potential” よりも“are potential”と書くこと）。しかし、結 論を一般化し過ぎてはならない。

・ジャーナル編集長が要求しない限り、数は、 zero、one（単位が無い場合）や誤解が生じそ うな場合（例：文書の始まりまたは数字を含む 略語の前）を除くと、1 桁の場合も全て数字で 書<（CSE 2014）。

\section{理解しやすくするために明確に書く：文書を読 みやすくする}

\section{科学的内容}

・他者や自分のこれまでの出版物における考えと 今回の研究のデータを明確に区別する。関連性 がある場合は常に引用する。翻訳する場合も含 め、その他の情報源の文書を要約または説明す ることが望ましい。そのまま文書（例：文書全 体または長文）をコピーする場合は、引用符の 中に記述する（例 : Roig 2011, Kerans \& de Jager 
2010）。そうでなければ、他者または自身の 剽窃になる可能性がある（COPE flowcharts 参 照）。

- 必ず英語の科学用語を正しく使用する。英語 ネイティブスピーカーが書いた文書に基づく のが望ましい。直訳は間違っている場合があ る（例：false friends 等似ているが意味の異なる 語、翻訳者が作り出したいわゆる存在しない 言葉の場合がある）。間違った言葉の使用が 多いので、疑問に思う場合は、英語辞書で調 ベる (Appendix: Ambiguity 参照)。また単語 やフレーズを Wikipedia で調べることができる。 例えば、母国語と英語で結果を比較し、想定 する言葉の意味が本当に同じかを調べる。し かし、Wikipedia は常に信頼できる情報源とは 限らない。

・ほとんどが訳文中で使用されており、英語圈 ではあまり見かけない言葉の場合は、同様な 意味を持つよく知られた英単語で置き換えて みる (例 : phytocoenosis を plant community で置 き換える）。科学用語の類義語が英語になけ れば、明確に定義し、好ましい英訳を提案す る。

・初回言及時に、共通でないまたは不明瞭な科 学用語を定義する。（検索支援のために）類 義語が複数あればリストにすることができる が、（混乱を避けるために）後でひとつだけ を採用すること。科学機関によって正式な用 語体系が確立されていれば、その用語を科学 コミュニケーションの際に使うべきである （例：EASE 2013）。

・読者に意味を推測させるような不明瞭な記述 はさける (Appendix: Ambiguity 参照)。

・割合を書く場合は、何を $100 \%$ とするかを明確 にする。相関や関係等について書く場合は、 どの值を比較しているのかを明確にする。

-「SI units」「Celsius degrees」が一般的に好ま れている。

-その他多くの言語と同様に、英語にも小数点 がある（コンマとは異なる）。ジャーナル編 集長が要求しない限りは、小数点の左右どち らかに 4 桁以上の数值がある場合は、小数点 から左右どちらにも3 桁毎に半角スペース （コンマとは異なる）を使用する（EASE 2013)。

-世紀や月等を表示する場合は、大文字のロー マ数字は英語ではまれなため使用しないこと。 英国と米国では日付の表記が異なるため（下
記参照）、「月」は単語全体または最初の 3 文 字で示すのが望ましい（CSE 2014）。

•あまり知られていない地名を翻訳する場合は、 可能な限り元の地名も記載すること。例えば、 “in the Kampinos Forest (Puszcza Kampinoska)”と記 載する。場所や気候等に関する付加情報は読者 にとって役に立つ場合がある。

-文書は主に外国人によって読まれることを忘れ てはならない。彼らはあなたの国では常識とな っている特定の状況や分類、概念を理解してい ないかもしれない。従って、補足説明が必要と なる場合がある（Ufnalska 2008）。例えば、よ く知られている雑草、Erigeron annuus は国によ っては Stenactis annua と呼ばれる。よって、英 文でも、国際的に認められている名前を使用し、 同意語を括弧の中に書くこと。

\section{文章構造}

•一般的に文は長すぎてはならない。構造は比較 的シンプルなものとし、主語は動詞の近くに置 くこと（Gopen \& Swan 1990）。例えば、抽象 名 詞は避け、“Measurements of X were carried out...”で はなく“X was measured...” と書く（Appendix: Simplicity 参照）。受身を多用しないこと（例： Norris 2011）。翻訳するときは、メッセージを 正確またはより明確に伝えるために、必要であ れば文章構造を修正すること（BurroughBoenisch 2013）。

・文章はまとまりのある論理的な構造であり、よ って理解しやすくすること（Appendix: Cohesion 参照) 。

・各段落は、トピックセンテンスから始まり、以 降の文はトピックを十分に発展させるものであ ること。

・他の言語とは対照的に、英語では理解を深める ために並列構造が認められている。例えば、類 似データを比較する場合に“It was high in A, medium for $\mathrm{B}$, and low in the case of $\mathrm{C}$ ”と書くよりも "It was high in A, medium in B, and low in C" と書くこ とができる。

・論文本文を参照することなく図表が容易に理解 できるようにすること。参考とならないデータ は省く（例：ある列の值が全ての行に含まれる 場合はその列を削除し、脚注に記述することが できる）。一貫性を保つために必要な場合、ま たは単語全体を記述するスペースが無い場合の み、略語を使用する。図表の説明文や脚注で、 
不明瞭な略語や記号を全て定義すること

(例 : エラーバーは、標準偏差または標準誤 差、信頼区間を示す場合がある）。小数点 （コンマとは異なる）を使うことを忘れない ようにし、必要なときは常に軸ラベルと単位 を表記する。

・小規模データ集団を扱うときは、表を使用す ることを考える（Kozak 2009）（Appendix: Text-tables 参照）。

- 長い一覧（略語等）の場合は、コンマとピリ オドの中間であるセミコロン（;）で個々の項 目を区切るのが望ましい。

\section{言語問題}

・科学用語が不要な場合は常に一般的な用語を 使うのが望ましい。但し、非英語ネイティブ スピーカーにとって理解しづらい場合がある ので、句動詞と同様に話し言葉や慣用語句は 避けること（例：find out, pay off）（Geercken 2006)。

- 論文本文における初回言及時に略語を定義す ること（読者にとってあいまいな場合）。文 章が理解しづらくなるので様々な略語を多用 しすぎないこと。論文の中でほとんど使われ ない用語は略さないこと。アブストラクトの 中での略語の使用は避けること。

-一般的に、研究をいかに行い何を見発見した か、または他の研究者が行った内容について は過去形を使用する。一般的な説明や解説 （例：統計的有意性、結論）、論文の内容、 特に図表の内容について記述する場合は現在 形が望ましい（Day \& Gastel 2006）。

- 不明瞭となるので、ジャーナル編集長が要求 しない限りは、自分自身のことを“ “he author(s)”と書かないこと。必要ならば“we” or “I”と書くか、または“"in this study”, “our results” または“in our opinion”といった表現を用いる

（例：Hartley 2010, Norris 2011）。自分の新しい 発見を示す場合に限り,“this study”と書くこと に留意する。過去の文書で示した出 版物を示 す場合は“that study”と書く。引用した 出版物 の著者を示す場合は“those authors”と書く

・科学文書では、制限用法では“that”（例：“only those that”を意味する場合）を用いるが、非制 限用法では“which”を用いること。

・曖昧な単語を使用する場合は、文脈の中で意 味を確実に明確にすること。動詞が主語の人
称と全て合っているか、代名詞が全て明確であ るか（これは翻訳文の場合は重要である）を確 認する。不規則複数形の名詞に留意すること

\section{(Appendix: Plurals 参照)。}

- 文書を声に出して読み句読点を確認する。正し く理解してもらうために、音調の切れ目をコン マやその他句読点で示す (例 : “no more data are needed”と“no, more data are needed”の違いに 留意 する）。

・スペルを一貫させる。スペルやデータの表記は、 英国式か米国式ルールのどちらかに従うこと

（例：英国式では“21 Jan 2009”、米国式では “Jan 21, 2009”）（Appendix: Spelling 参照）。目標ジャ 一ナルが米国式と英国式のどちらのスペルを 使用しているか確認し、スペルチェックと文章 校正の設定を合わせる。

・曖昧な箇所が無いか確認するために、親切な同 僚に文書を全部読んでもらうよう依頼する。

翻訳 / Translation: Yukari Taki, Edanz Group Japan (エダンズ グループ ジャパン, http://www.edanzediting.co.jp/)

ご助言いただいた関係各位を含む「本ガイドラインへのご 協力者 (時系列順) 」: Sylwia Ufnalska (initiator and editor, sylwia.ufnalska@gmail.com), Paola De Castro, Liz Wager, Carol Norris, James Hartley, Françoise Salager-Meyer, Marcin Kozak, Ed Hull, Angela Turner, Will Hughes, Peter Hovenkamp, Thomas Babor, Eric Lichtfouse, Richard Hurley, Mercè Piqueras, Maria Persson, Elisabetta Poltronieri, Suzanne Lapstun, MareAnne Laane, David Vaux, Arjan Polderman, Ana Marusic, Elisabeth Heseltine, Joy Burrough-Boenisch, Eva Baranyiová, Tom Lang, Arie Manten, Pippa Smart, Armen Gasparyan, John Miescher, Shirin Heidari, Ksenija Baždarić

\section{参考文献およびその他}

AuthorAID Resource Library. http://www.authoraid.info/resourcelibrary

Baranyiová E. 2013. Correct terminology in science: the role of editors.

Science Editor 36 (2): 63. http://www.

councilscienceeditors.org/wp-content/uploads/v36n2p63.pdf

Battisti WP, Wager E, Baltzer L, Bridges D, Cairns A, Carswell CI, et al

2015. Good publication practice for communicating companysponsored medical research: GPP3. Annals of Internal Medicine 163(6):461-464. doi:10.7326/M15-0288

Beverley P. 2015. Word macros for writers and editors. http://www.archivepub.co.uk/TheBook

BioMed Central policy on duplicate publication. $\mathrm{http} / /$ www.biomedcentral.com/submissions/editorialpolicies\#duplicate+publication

Bless A, Hull E. 2008. Reader-friendly biomedical articles: how to write them! 3rd ed. Alphen a/d Rijn: Van Zuiden Communication.

Bravo E, Calzolari A, De Castro P, Mabile L, Napolitani F, Rossi AM, Cambon-Thomsen A. 2015. Developing a guideline to standardize the citation of bioresources in journal articles (CoBRA). BMC Medicine 13:33.doi:10.1186/s12916-015-0266-y

Burrough-Boenisch J. 2013. Editing texts by non-native speakers of English. In: European Association of Science Editors. Science editors' handbook. Smart P, Maisonneuve H, Polderman A, editors. http://www.ease.org.uk/handbook/index.shtml

Cerejo C. 2013. How to make your paper more accessible through self-archiving. Editage Insights. http://www.editage. 
com/insights/how-to-make-your-paper-more-accessiblethrough-self-archiving

Chipperfield L, Citrome L, Clark J, David FS, Enck R, Evangelista M, et al 2010. Authors' Submission Toolkit: a practical guide to getting your research published. Current Medical Research \& Opinion 26(8):1967-1982. doi:10.1185/03007995.2010.499 344

[COPE flowcharts] Committee on Publication Ethics flowcharts. http://publicationethics.org/resources/flowcharts

[CSE] Council of Science Editors, Style Manual Committee. 2014. Scientific style and format: the CSE manual for authors, editors, and publishers. 8th ed. Univeristy of Chicago Press. http://www.scientificstyleandformat.org/Home.html

Day RA, Gastel B. 2006. How to write and publish a scientific paper. 6th ed. Cambridge: Cambridge University Press.

[DORA] San Francisco Declaration on Research Assessment. 2013. http://www.ascb.org/dora/

[EASE] European Association of Science Editors. 2012. EASE Toolkit for Authors. http://www.ease.org.uk/publications/ ease-toolkit-authors

[EASE] European Association of Science Editors. 2013. Science editors' handbook. 2nd ed. Smart P, Maisonneuve H, Polderman A, editors. http://www.ease.org.uk/publications/ science-editors-handbook/

EQUATOR Network. http://www.equator-network.org/

Gasparyan AY, Ayvazyan L, Blackmore H, Kitas GD. 2011. Writing a narrative biomedical review: considerations for authors, peer reviewers, and editors. Rheumatology International 31(11):1409-1417. doi: 10.1007/ s00296-011-1999-3

Geercken S. 2006. Challenges of (medical) writing for the multilingual audience. Write Stuff 15(2):45-46. http://www. emwa.org/documents/journal/TWS/TWS\%202006\%20 2\%2015.pdf

Goozner M, Caplan A, Moreno J, Kramer BS, Babor TF, Husser WC. 2009. A common standard for conflict of interest disclosure in addiction journals. Addiction 104:1779-1784. doi: 10.1111/j.1360-0443.2009.02594.x

Gopen GD, Swan JA. 1990. The science of scientific writing: if the reader is to grasp what the writer means, the writer must understand what the reader needs. American Scientist 78(6):550-558. http://www-stat.wharton.upenn.edu/ buja/ sci.html

Hartley J. 2010. Citing oneself. European Science Editing 36(2):3537. http://www.ease.org.uk/sites/default/files/may_2010_362. pdf

Heidari S, Babor TF, De Castro P, Tort S, Curno M. 2016. Sex and Gender Equity in Research: rationale for the SAGER guidelines and recommended use. Research Integrity and Peer Review 1:2. doi: 10.1186/s41073-016-0007-6

Hengl T, Gould M, Gerritsma W. 2012. The unofficial guide for authors: from research design to publication. Wageningen, Arnhem. http://www.lulu.com/spotlight/t_hengl

Hull E. 2015. Health-related scientific articles in the 21st century: give readers nuggets! Vught, Netherlands: Professional English. http://www.professionalenglish.nl/giveemnuggets.html
[ICMJE] International Committee of Medical Journal Editors. 2015. Recommendations for the Conduct, Reporting, Editing, and Publication of Scholarly Work in Medical Journals. http:// www.icmje.org/urm_main.html

[Inderscience] Inderscience Publishers. 2013. Keyword requirements. http://www.inderscience.com/info/insitemap. php

Kerans ME, de Jager M. 2010. Handling plagiarism at the editor's desk. European Science Editing 36(3): 62-66. http://www.ease. org.uk/sites/default/files/ese_aug10.pdf

Kozak M. 2009. Text-table: an underused and undervalued tool for communicating information. European Science Editing 35(4):103. http://www.ease.org.uk/sites/default/files/ november_2009_354.pdf_

Lang T. 2004. Twenty statistical errors even YOU can find in biomedical research articles. Croatian Medical Journal 45(4):361-370. http://www.cmj.hr/2004/45/4/15311405.htm

Marusic M. 2014. Gender and sex in medical research. European Science Editing 40(2):56. http://www.ease.org.uk/sites/default/ files/corresp_2.pdf

[MeSH Browser] Medical Subject Headings Browser. http://www. nlm.nih.gov/mesh/MBrowser.html

Norris CB. 2009. Academic writing in English. Helsinki: University of Helsinki. http://www.helsinki.fi/kksc/language. services/AcadWrit.pdf

Norris C. 2011. The passive voice revisited. European Science Editing 37(1):6-7. http://www.ease.org.uk/sites/default/files/ february_2011_371.pdf

O’Connor M. 1991. Writing successfully in science. London: Chapman \& Hall.

Research Methods Supercourse. http://www.pitt.edu/ super1/ ResearchMethods/index.htm

[RIN] Research Information Network. 2008. Acknowledgement of funders in journal articles. http://www.rin.ac.uk/ our-work/research-funding-policy-and-guidance/ acknowledgement-funders-journal-articles

Roig M. 2011. Avoiding plagiarism, self-plagiarism, and other questionable writing practices: a guide to ethical writing. Office of Research Integrity http://ori.hhs.gov/education/products/ plagiarism/0.shtml

Seifert KA, Crous PW, Frisvad JC. 2008. Correcting the impact factors of taxonomic journals by Appropriate Citation of Taxonomy (ACT). Persoonia 20:105. doi: $10.3767 / 003158508 X 324236$

Strunk WJr, White EB. 2000. The elements of style. $4^{\text {th }} \mathrm{ed}$. New York: Macmillan.

Tufte ER. 2001. The visual display of quantitative information, 2nd ed. Cheshire, CT: Graphics Press.

Ufnalska S. 2008. Abstracts of research articles: readers' expectations and guidelines for authors. European Science Editing 34(3):63-65. http://www.ease.org.uk/sites/default/files/august_2008343.pdf [WMA] World Medical Association. 2013. Declaration of Helsinki - ethical principles for medical research involving human subjects. http://www.wma.net/en/30publications/10policies/b3/

World Conference on Research Integrity. 2010. Singapore Statement. http://www.singaporestatement.org/statement.html 


\section{Key elements of abstracts}

Researchers are quite often in a "box" of technical details - the "important" things they focus on day in and day out. As a result, they frequently lose sight of 4 items essential for any readable, credible, and relevant $\mathrm{IMRaD}^{1}$ article: the point of the research, the research question, its answer, and the consequences of the study.

To help researchers to get out of the box, I ask them to include 5 key elements in their research report and in their abstract. I describe briefly the elements below and illustrate them with a fictitious abstract.

Key element 1 (BACKGROUND): the point of the research - why should we care about the study? This is usually a statement of the BIG problem that the research helps to solve and the strategy for helping to solve it. It prepares the reader to understand the specific research question.

Key element 2 (OBJECTIVES): the specific research question - the basis of credible science. To be clear, complete and concise, research questions are stated in terms of relationships between the variables that were investigated. Such specific research questions tie the story together they focus on credible science.

Key element 3 (METHODS): a precise description of the methods used to collect data and determine the relationships between the variables.

Key element 4 (RESULTS): the major findings - not only data, but the RELATIONSHIPS found that lead to the answer. Results should generally be reported in the past tense but the authors' interpretation of the factual findings is in the present tense - it reports the authors' belief of how the world IS. Of course, in a pilot study such as the following example, the authors cannot yet present definitive answers, which they indicate by using the words "suggest" and "may".
Key element 5 (CONCLUSIONS): the consequences of the answers - the value of the work. This element relates directly back to the big problem: how the study helps to solve the problem, and it also points to the next step in research.

Here is a fictitious structured abstract, using these headings.

\section{Predicting malaria epidemics in Ethiopia}

\section{Abstract}

BACKGROUND: Most deaths from malaria could be prevented if malaria epidemics could be predicted in local areas, allowing medical facilities to be mobilized early. OBJECTIVES: As a first step toward constructing a predictive model, we determined correlations between meteorological factors and malaria epidemics in Ethiopia. METHODS: In a retrospective study, we collected meteorological and epidemic data for 10 local areas, covering the years 1963-2006. Poisson regression was used to compare the data. RESULTS: Factors AAA, BBB, and CCC correlated significantly $(P<0.05)$ with subsequent epidemics in all 10 areas. A model based on these correlations would have a predictive power of about $30 \%$. CONCLUSIONS: Meteorological factors can be used to predict malaria epidemics. However, the predictive power of our model needs to be improved and validated in other areas.

This understandable and concise abstract forms the "skeleton" for the entire article. A final comment: This example is based on an actual research project and, at first, the author was in a "box" full of the mathematics, statistics, and computer algorithms of his predicting model. This was reflected in his first version of the abstract, where the word "malaria" never appeared.

Written by Ed Hull edhull@home.nl (for more information, see Hull 2015) 


\section{Empty words and sentences}

Many English words are empty - they do not add information but require the reader to fill in information or context to be understood. The reader is forced to supply his or her own interpretation, which could be different from what you, the writer, mean.

Empty words seem to give information and uncritical readers do not notice them - that is why they work so well for marketing texts. However, empty words do not belong in articles reporting scientific research. Empty words require the reader to supply the meaning - very dangerous. Concise and clear communication requires words that convey specific meaning.

\section{Examples}

It is important that patients take their medicine.

- Note that to a physician the meaning is probably entirely different than to the sales manager of a pharmaceutical company. "Important" is one of our best-loved, but empty, words - it fits every situation.

The patient was treated for XXX.

- "Treated" is empty; we do not know what was done. One reader could assume that the patient was given a certain medicine, while another reader could assume that the patient was given a different medicine. Perhaps the patient was operated on, or sent to Switzerland for a rest cure.

The patient reacted well to the medicine.

- "Reacted well" gives us a positive piece of information, but otherwise it is empty; we do not know how the patient reacted.
The patient's blood pressure was low.

- We interpret "high/low blood pressure" to mean "higher/lower than normal", but we, the readers, have to supply that reference standard. A more concise statement is: The patient's blood pressure was 90/60.

Empty words and phrases not only require the reader to supply the meaning, they also contribute to a wordy blahblah text. In scientific articles they destroy credibility. Here are some examples.

It has been found that the secondary effects of this drug include...

- Better: The secondary effects of this drug include...(ref.). Or, if these are your new results: Our results show that the secondary effects of this drug include...

We performed a retrospective evaluation study on XXX.

- "Performed a study" is a much overused and rather empty phrase. Better: We retrospectively evaluated XXX.

More examples that require the reader to supply information if it is not evident from the context:

- quality

- $\mathrm{good} / \mathrm{bad}$

- high/low

- large/small

- long/short

- proper/properly (eg “...a proper question on the questionnaire...")

- As soon as possible...
Written by Ed Hull edhull@home.nl

\section{Incorrect use of scientific terms}

Scientific language should be exact and based on unequivocal terms. However, some terms are not always used properly. For example, trimester means 3 months (usually with reference to $1 / 3$ of human pregnancy) but is often wrongly used to describe $1 / 3$ of mostly shorter pregnancy in many animal species (Baranyiová 2013). Another nowadays frequently misused word in both human and veterinary medicine is gender (eg "examined dogs of both genders"), as it is not equivalent to biological sex. The word gender applies primarily to social and linguistic contexts. By contrast, in medicine and biology, the term sex is usually correct, because biological sex (not gender) is linked with major physiological differences (Marušić 2014). Wrong use of scientific terms can lead not only to confusion but also to serious consequences, so special care should be taken to avoid it.

Written by Eva Baranyiová ebaranyi@seznam.cz 


\section{Cohesion - the glue}

The word "cohesion" means "unity", "consistency", and "solidity". Building cohesion into your text makes life easier for your readers - they will be much more likely to read the text. Cohesion "glues" your text together, focusing the readers' attention on your main message and thereby adding credibility to your work.

Think of your text as a motorcycle chain made up of separate links, where each sentence is one link. A pile of unconnected links is worthless - it will never drive your motorcycle. Similarly, a pile of unconnected sentences is worthless - it will never drive your message home.

To build a cohesive text, you have to connect your sentences together to make longer segments we call paragraphs. A cohesive paragraph clearly focuses on its topic. You then need to connect each paragraph with the previous paragraph, thereby linking the paragraph topics. Linking paragraphs results in building cohesive sections of your article, where each section focuses on its main topic. Then, link the sections to each other and, finally, connect the end of your article to the beginning, closing the loop - now the chain will drive our motorcycle. Let's look at linking techniques.

\section{Basic guidelines for building a cohesive story:}

1. Link each sentence to the previous sentence.

2. Link each paragraph to the previous paragraph.

3. Link each section to the previous section.

4. Link the end to the beginning.

\section{Linking techniques}

Whether you want to link sentences, paragraphs, sections or the beginning to the end, use 2 basic linking techniques:
- Use linking words and phrases, such as: however, although, those, since then... An example: Our research results conflict with those of Smith and Jones. To resolve those differences we measured ...

- Repeat key words and phrases - do not use synonyms. In scientific writing, repetition sharpens the focus. Repetition especially helps the reader to connect ideas that are physically separated in your text. For example: Other investigators have shown that microbial activity can cause immobilization of labile soil phosphorus. Our results suggest that, indeed, microbial activity immobilizes the labile soil phosphorus.

The example below illustrates how to link your answer to your research question, thus linking the Discussion with the Introduction.

In the Introduction, the research hypothesis is stated. For example: The decremental theory of aging led us to hypothesize that older workers in "speed" jobs perform less well and have more absences and more accidents than other workers have.

In the Discussion, the answer is linked to the hypothesis: Our findings do not support the hypothesis that older workers in speed jobs perform less well and have more absences and more accidents than other workers have. The older workers generally earned more, were absent less often, and had fewer accidents than younger workers had. Furthermore, we found no significant difference between...

Written by Ed Hull edhull@home.nl 


\section{EASE Ethics Checklist for Authors}

EXPLANATION: obligatory declarations applying to all manuscripts are printed in bold.

\section{Original or acceptable secondary publication}

$\square$ No part of this manuscript (MS) has been published, except for passages that are properly cited.

$\square$ An abstract/summary of this MS has been published

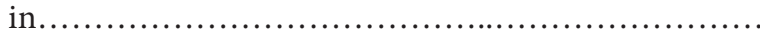

n.m.

This MS has already been published in

but in language. A full citation to the primary publication is included, and the copyright owner has agreed to its publication in English.

No part of this MS is currently being considered for publication elsewhere.

$\square$ In this MS, original data are clearly distinguished from published data. All information extracted from other publications is provided with citations.

\section{Authorship}

$\square$ All people listed as authors of this MS meet the authorship criteria, ie they contributed substantially to study planning, data collection or interpretation of results and wrote or critically revised the MS and approved its final submitted version and agree to be accountable for all aspects of the work (ICMJE 2015).

All people listed as authors of this MS are aware of it and have agreed to be listed.

$\square$ No person who meets the authorship criteria has been omitted.

\section{Ethical experimentation and interpretation}

$\square$ The study reported in this MS involved human participants and it meets the ethical principles of the Declaration of Helsinki (WMA 2013). Data have been disaggregated by sex (and, whenever possible, by race) and sex and gender considerations are properly addressed (see Sex and Gender Questions ${ }^{2}$ ).

$\square$ The study reported in this MS meets the Consensus Author Guidelines on Animal Ethics and Welfare for Veterinary Journals ${ }^{3}$ about humane treatment of animals and has been approved by an ethical review committee.

$\square$ The study reported in this MS meets other ethical principles, namely

$\square$ I and all the other authors of this MS did our best to avoid errors in experimental design, data presentation, interpretation, etc. However, if we discover any serious error in the MS (before or after publication), we will alert the editor promptly.

$\square$ None of our data presented in this MS has been fabricated or distorted, and no valid data have been excluded. Images shown in figures have not been manipulated to make a false impression on readers.

$\square$ Results of this study have been interpreted objectively. Any findings that run contrary to our point of view are discussed in the MS.

$\square$ The article does not, to the best of our knowledge, contain anything that is libellous, illegal, infringes anyone's copyright or other rights, or poses a threat to public safety.

\section{Acknowledgements}

$\square$ All sources of funding for the study reported in this MS are stated.

$\square$ All people who are not listed as authors but contributed considerably to the study reported in this MS or assisted in its writing (eg author's editors, translators, medical writers) are mentioned in the Acknowledgements.

$\square$ All people named in the Acknowledgements have agreed to this. However, they are not responsible for the final version of this MS.

$\square$ Consent has been obtained from the author(s) of unpublished data cited in the MS.

$\square$ Copyright owners of previously published figures or tables have agreed to their inclusion in this MS.

\section{Conflict of interest}

$\square$ All authors of this study have signed the EASE Form for Authors' Contributions and Conflict of Interest Disclosure ${ }^{4}$.

Date:.

Corresponding author:

MS title:

Compiled by Sylwia Ufnalska sylwia.ufnalska@gmail.com

\footnotetext{
${ }^{2}$ http://www.ease.org.uk/publications/sex-and-gender

${ }^{3}$ http://www.veteditors.org/consensus-author-guidelines-onanimal-ethics-and-welfare-for-editors/

${ }^{4}$ www.ease.org.uk/publications/ease-form
} 
Appendix: Plurals

\section{Examples of irregular plurals deriving from Latin or Greek}

\begin{tabular}{|c|c|c|}
\hline Singular & Plural & Examples \\
\hline$-a$ & $\begin{array}{l}-a e \\
\text { rarely -ata }\end{array}$ & $\begin{array}{l}\text { alga - algae, larva-larvae } \\
\text { stoma - stomata }\end{array}$ \\
\hline$-e x$ & -ices & $\begin{array}{l}\text { index - indices }(\text { or indexes } * \text { ) } \\
\text { apex-apices }\left(\text { or } \text { apexes }^{*}\right)\end{array}$ \\
\hline -ies & -ies & species, series, facies \\
\hline$-i s$ & $-e s$ & axis - axes, hypothesis - hypotheses \\
\hline$-i x$ & -ices & $\begin{array}{l}\text { appendix - appendices (or appendixes } * \text { ) } \\
\text { matrix - matrices (or matrixes } * \text { ) }\end{array}$ \\
\hline$-o n$ & $-a$ & $\begin{array}{l}\text { phenomenon - phenomena } \\
\text { criterion - criteria }\end{array}$ \\
\hline$-u m$ & $-a$ & datum-data**, bacterium-bacteria \\
\hline$-u s$ & $\begin{array}{l}-\boldsymbol{i} \\
\text { rarely -uses } \\
\text { or -era }\end{array}$ & $\begin{array}{l}\left.\text { locus - loci, fungus - fungi (or funguses }{ }^{*}\right) \\
\text { sinus - sinuses } \\
\text { genus - genera }\end{array}$ \\
\hline
\end{tabular}

* Acceptable anglicized plurals that are also listed in dictionaries.

${ }^{* *}$ In non-scientific use, usually treated as a mass noun (like information, etc.)

It must be remembered that some nouns used in everyday English also have irregular plural forms (e.g. woman women, foot - feet, tooth - teeth, mouse - mice, leaf - leaves, life - lives, tomato - tomatoes) or have no plural form (e.g. equipment, information, news). For more examples, see CSE (2014). If in doubt, consult a dictionary. 


\section{Appendix: Simplicity}

\section{Examples of expressions that can be simplified or deleted $(\varnothing)$}

\begin{tabular}{|c|c|}
\hline Long or (sometimes) wrong & Better choice (often) \\
\hline accounted for by the fact that & because \\
\hline $\begin{array}{l}\text { as can be seen from Figure 1, substance } Z \\
\text { reduces twitching }\end{array}$ & substance $Z$ reduces twitching (Fig. 1) \\
\hline at the present moment & now \\
\hline bright yellow in colour & bright yellow \\
\hline conducted inoculation experiments on & inoculated \\
\hline considerable amount of & much \\
\hline despite the fact that & although \\
\hline due to the fact that & because \\
\hline for the reason that & because \\
\hline if conditions are such that & if \\
\hline in a considerable number of cases & often \\
\hline in view of the fact that & because \\
\hline it is of interest to note that & $\varnothing$ \\
\hline it may, however, be noted that & but \\
\hline large numbers of & many \\
\hline lazy in character & lazy \\
\hline methodology & methods \\
\hline owing to the fact that & because \\
\hline oval in shape & oval \\
\hline prior to & before \\
\hline taken into consideration & considered \\
\hline terminate & end \\
\hline the test in question & this test \\
\hline there can be little doubt that this is & this is probably \\
\hline to an extent equal to that of $X$ & as much as $X$ \\
\hline utilize & use \\
\hline whether or not & whether \\
\hline
\end{tabular}




\section{Examples of differences between British and American spelling}

\begin{tabular}{|c|c|}
\hline British English & American English \\
\hline $\begin{array}{c}-\boldsymbol{a e}- \\
\text { eg aetiology, faeces, haematology }\end{array}$ & $\begin{array}{c}-\boldsymbol{e}- \\
\text { eg etiology, feces, hematology }\end{array}$ \\
\hline $\begin{array}{l}\text {-ce in nouns, }-\boldsymbol{s e} \text { in verbs } \\
\text { eg defence, licence/license, practice/practise }\end{array}$ & $\begin{array}{l}\text {-se in nouns and verbs } \\
\text { eg defense, license } \\
\text { (but practice as both noun and verb) }\end{array}$ \\
\hline $\begin{array}{c}\text {-ise } \text { or }- \text { ize } \\
\text { eg organise/organize }\end{array}$ & $\begin{array}{c}\text {-ize } \\
\text { eg organize }\end{array}$ \\
\hline $\begin{array}{c}\text {-isation or -ization } \\
\text { eg organisation/organization }\end{array}$ & $\begin{array}{c}\text {-ization } \\
\text { eg organization } \\
\end{array}$ \\
\hline $\begin{array}{l}\text {-lled, -lling, -llor, etc. } \\
\text { eg labelled, travelling, councillor } \\
\text { (but fulfil, skilful) }\end{array}$ & $\begin{array}{l}\text {-led, -ling, -lor, etc. } \\
\text { eg labeled, traveling, councilor } \\
\text { (but fulfill, skillful) }\end{array}$ \\
\hline $\begin{array}{c}-\boldsymbol{o e}- \\
\text { eg diarrhoea, foetus, oestrogen }\end{array}$ & $\begin{array}{c}-\boldsymbol{e}- \\
\text { eg diarrhea, fetus, estrogen }\end{array}$ \\
\hline $\begin{array}{c}\text {-ogue } \\
\text { eg analogue, catalogue }\end{array}$ & $\begin{array}{c}-o g \text { or -ogue } \\
\text { eg analog/analogue, catalog/catalogue }\end{array}$ \\
\hline $\begin{array}{c}\text {-our } \\
\text { eg colour, behaviour, favour }\end{array}$ & $\begin{array}{c}-o r \\
\text { eg color, behavior, favor }\end{array}$ \\
\hline $\begin{array}{c}\text {-re } \\
\text { eg centre, fibre, metre, litre } \\
\text { (but meter for a measuring instrument) }\end{array}$ & $\begin{array}{c}-e r \\
\text { eg center, fiber, meter, liter }\end{array}$ \\
\hline $\begin{array}{c}\text {-yse } \\
\text { eg analyse, dialyse }\end{array}$ & $\begin{array}{c}\text {-yze } \\
\text { eg analyze, dialyze }\end{array}$ \\
\hline aluminium & aluminum or aluminium ${ }^{\star *}$ \\
\hline grey & gray \\
\hline mould & mold \\
\hline programme (general) or program (computer) & program \\
\hline sulphur or sulfur ${ }^{* *}$ & sulfur \\
\hline
\end{tabular}

${ }^{\star}$ One ending should be used consistently.

${ }^{\star *}$ Recommended by the International Union of Pure and Applied Chemistry and the Royal Society of Chemistry.

For more examples, see CSE (2014). If in doubt, consult a dictionary. Obviously, American and British English slightly differ not only in spelling but also in word use, grammar, punctuation, etc. However, those differences are outside the scope of this document.
Compiled by Sylwia Ufnalska sylwia.ufnalska@gmail.com 


\section{Text-tables - effective tools for presentation of small data sets}

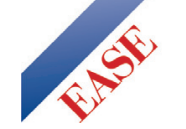

Arranging statistical information in a classic table and referring to it elsewhere means that readers do not access the information as immediately as they would when reading about it within the sentence. They have to find the table in the document (which may be on another page), losing some time. This slightly decreases the strength of the information. Quicker access to the information can be achieved within a sentence, but this is not an effective structure if more than 2 numbers are to be compared. In such situations, a "text-table" appears to be ideal for communicating information to the reader quickly and comprehensibly (Tufte 2001). The texttable is a simple table with no graphic elements, such as grid lines, rules, shading, or boxes. The text-table is embedded within a sentence, so no reference to it is needed. Keeping the power of tabular arrangements, text-tables immediately convey the message. Look at the following examples.

\section{Original sentence:}

Iron concentration means ( \pm standard deviation) were as follows: $11.2 \pm 0.3 \mathrm{mg} / \mathrm{dm}^{3}$ in sample $\mathrm{A}, 12.3 \pm 0.2 \mathrm{mg} / \mathrm{dm}^{3}$ in sample $B$, and $11.4 \pm 0.9 \mathrm{mg} / \mathrm{dm}^{3}$ in sample C.

\section{Modified:}

Iron concentration means ( \pm standard deviation, in $\mathrm{mg} /$ $\mathrm{dm}^{3}$ ) were as follows:

$$
\begin{array}{ll}
\text { sample B } & 12.3 \pm 0.2 \\
\text { sample C } & 11.4 \pm 0.9 \\
\text { sample A } & 11.2 \pm 0.3
\end{array}
$$

\section{Original sentence}

After the treatment was introduced, mortality tended to decline among patients aged 20-39 y (relative reduction $[\mathrm{RR}]=0.86 / \mathrm{y} ; 95 \%$ CI $0.81-0.92 ; P<0.001), 40$ to $59 \mathrm{y}$ of age $(\mathrm{RR}=0.97 / \mathrm{y} ; 95 \% \mathrm{CI} 0.92-1.03 ; P=0.24)$ and 60 to 79 y of age $(\mathrm{RR}=0.92 / \mathrm{y} ; 95 \%$ CI $0.86-0.99 ; P=0.06)$.

\section{Modified:}

After the treatment was introduced, mortality tended to decline among patients in all age groups (RR stands for relative reduction per year):
20-39y RR $=0.86 \quad$ (95\% CI 0.81-0.92; $P<0.001)$
$40-59$ y $\mathrm{RR}=0.97 \quad(95 \%$ CI $0.92-1.03 ; P=0.24)$
$60-79$ y RR $=0.92 \quad(95 \%$ CI $0.86-0.99 ; P=0.06)$

\section{Some rules for arranging text-tables}

1. The larger a text-table is, the less power it has.

2. The sentence that precedes the text-table acts as a heading that introduces the information the text-table represents, and usually ends with a colon. Text-tables should have neither headings nor footnotes.

3. Indentation of text-tables should fit the document's layout.

4. Occasional changes in font (such as italics, bold, a different typeface) may be used, but with caution. They can, however, put some emphasis on the tabular part.

5. Do not use too many text-tables in one document or on one page.

6. In addition to the above rules, apply rules for formatting regular tables. For example, numbers should be given in 2-3 effective digits; ordering rows by size and their correct alignment will facilitate reading and comparison of values; space between columns should be neither too wide nor too narrow.

Written by Marcin Kozak nyggus@gmail.com (for more information, see Kozak 2009)

\section{Practical tips for junior researchers}

- Consider publishing a review article once you have completed the first year of your PhD studies because: (1) you should already have a clear picture of the field and an up-to-date stock of references in your computer; (2) research results sometimes take a long time to get (in agronomy: 3 years of field experiments...); (3) journals love review articles (they tend to improve the impact factor); (4) the rejection rate of review articles is low (although some journals publish solicited reviews only, so you might want to contact the Editor first); (5) the non-specialist reader - such as a future employer - will understand a review article more easily than an original article with detailed results.

- Alternatively, publish meta-analyses or other databasebased research articles.
- Each part/item of an article should preferably be "almost" understandable (and citable) without reading other parts. The average time spent reading an article is falling, so virtually no one reads from Title to References. This phenomenon is amplified by the "digital explosion", whereby search engines identify individual items, such as abstracts or figures, rather than intact articles.

Written by Eric Lichtfouse eric.lichtfouse@dijon.inra.fr

For more advice, see EASE Toolkit for Authors

(www.ease.org.uk/publications/ease-toolkit-authors) 


\section{Background information about EASE and the EASE Guidelines}

The European Association of Science Editors (EASE) was formed in May 1982 at Pau, France, from the European Life Science Editors' Association (ELSE) and the European Association of Earth Science Editors (Editerra). Thus in 2012 we celebrated the $30^{\text {th }}$ anniversary of our Association.

EASE is affiliated to the International Union of Biological Sciences (IUBS), the International Union of Geological Sciences (IUGS), the International Organization for Standardization (ISO). Through its affiliation to IUBS and IUGS, our Association is also affiliated to the International Council for Science (ICSU) and is thereby in formal associate relations with UNESCO.

EASE cooperates with the International Society for Addiction Journal Editors (ISAJE), International Association of Veterinary Editors (IAVE), International Society of Managing and Technical Editors (ISMTE), the Council of Science Editors (CSE), and the Association of Earth Science Editors (AESE) in North America. Our other links include the African Association of Science Editors (AASE), the Association of Learned and Professional Society Publishers (ALPSP), the European Medical Writers Association (EMWA), Mediterranean Editors and Translators (MET), the Society of English-Native-Speaking Editors (Netherlands) (SENSE), and the Society for Editors and Proofreaders (SfEP).

We have major conferences every 2-3 years in various countries. EASE also organizes occasional seminars, courses, and other events between the conferences.

Since 1986, we publish a journal, now entitled European Science Editing. It is distributed to all members 4 times a year. It covers all aspects of editing and includes original articles and meeting reports, announces new developments and forthcoming events, reviews books, software and online resources, and highlights publications of interest to members. To facilitate the exchange of ideas between members, we also use an electronic EASE Forum, the EASE Journal Blog, and our website (www.ease.org.uk).

In 2007, we issued the EASE statement on inappropriate use of impact factors. Its major objective was to recommend that "journal impact factors are used only - and cautiously - for measuring and comparing the influence of entire journals, but not for the assessment of single papers, and certainly not for the assessment of researchers or research programmes either directly or as a surrogate".

In 2010, we published EASE Guidelines for Authors and Translators of Scientific Articles. Our goal was to make international scientific communication more efficient and help prevent scientific misconduct. This document is a set of generalized editorial recommendations concerning scientific articles to be published in English. We believe that if authors and translators follow these recommendations before submission, their manuscripts will be more likely to be accepted for publication. Moreover, the editorial process will probably be faster, so authors, translators, reviewers and editors will then save time.

EASE Guidelines are a result of long discussions on the EASE Forum and during our 2009 conference in Pisa, followed by consultations within the Council. The document is updated annually and is already available in 24 languages: Arabic, Bangla, Bosnian, Bulgarian, Chinese, Croatian, Czech, English, Estonian, French, German, Hungarian, Italian, Japanese, Korean, Persian, Polish, Portuguese (Brazilian), Romanian, Russian, Serbian, Spanish, Turkish, and Vietnamese. The English original and its translations can be freely downloaded as PDFs from our website. We invite volunteers to translate the document into other languages.

Many institutions promote EASE Guidelines (eg see the European Commission Research \& Innovation website), and many articles about this document have been published. Scientific journals also help in its popularization, by adding at the beginning of their instructions for authors a formula like:

Before submission, follow EASE Guidelines for Authors and Translators, freely available at www.ease.org.uk/ publications/author-guidelines in many languages. Adherence should increase the chances of acceptance of submitted manuscripts.

In 2012 we launched the EASE Toolkit for Authors, freely available on our website. The Toolkit supplements EASE Guidelines and includes more detailed recommendations and resources on scientific writing and publishing for less experienced researchers. In the same year, the EASE Gender Policy Committee was established to develop a set of guidelines for reporting of Sex and Gender Equity in Research (SAGER). Besides, EASE participated in the sTANDEM project (www.standem.eu), concerning standardized tests of professional English for healthcare professionals worldwide. Our Association also supports the campaign AllTrials (www.alltrials.net).

For more information about our Association, member's benefits, and major conferences, see the next page and our website. 


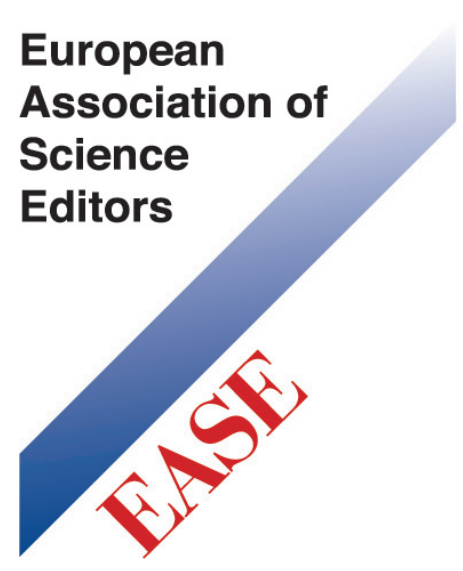

\section{Skills - communication - fellowship}

EASE is an internationally oriented community of individuals from diverse backgrounds, linguistic traditions, and professional experience, who share an interest in science communication and editing. Our Association offers the opportunity to stay abreast of trends in the rapidly changing environment of scientific publishing, whether traditional or electronic. As an EASE member, you can sharpen your editing, writing and thinking skills; broaden your outlook through encounters with people of different backgrounds and experience, or deepen your understanding of significant issues and specific working tools. Finally, in EASE we have fun and enjoy learning from each other while upholding the highest standards

\section{EASE membership offers the following benefits}

- A quarterly journal, European Science Editing, featuring articles related to science and editing book and web reviews, regional and country news, and resources

- A major conference every 2 years

- Seminars and workshops on topics in science editing

- Science Editors' Handbook (free online access, discount on printed version), covering all aspects of journal editing from on-screen editing to office management, peer review, and dealing with the media

- Advertising of your courses or services free of charge on the EASE website

- Discounts on job advertisements on the EASE website

- Opportunities to share problems and solutions with international colleagues from many disciplines (also on the EASE forum and ESE journal blog)

- Good networking and contacts for freelancers

- Discounts on editorial software, courses, etc.

\section{Our members}

EASE welcomes members from every corner of the world. They can be found in 50 countries: from Australia to Venezuela by way of China, Russia and many more. EASE membership cuts across many disciplines and professions. Members work as commissioning editors, academics, translators, publishers, web and multimedia staff, indexers, graphic designers, statistical editors, science and technical writers, author's editors, journalists, proofreaders, and production personnel.

\section{Major conferences}

\author{
2016 Strasbourg, France \\ 2014 Split, Croatia \\ 2012 Tallinn, Estonia (30th Anniversary) \\ 2009 Pisa, Italy \\ 2006 Kraków, Poland \\ 2003 Bath, UK \\ 2003 Halifax, Nova Scotia, Canada \\ (joint meeting with AESE) \\ 2000 Tours, France \\ 1998 Washington, DC, USA (joint meeting \\ with $(B E$ and $A E S E$ )
}

\author{
1997 Helsinki, Finland \\ 1994 Budapest, Hungary \\ 1991 Oxford, UK \\ 1989 Ottawa, Canada (joint meeting with \\ CBE and AESE) \\ 1988 Basel, Switzerland \\ 1985 Holmenkollen, Norway \\ 1984 Cambridge, UK \\ 1982 Pau, France
}

\footnotetext{
Disclaimer: Only the English version of EASE Guidelines has been fully approved by the EASE Council. Translations into other languages are provided as a service to our readers and have not been validated by EASE or any other organisation. EASE therefore accepts no legal responsibility for the consequences of the use of the translations. Recommended citation format of the English version:

[EASE] European Association of Science Editors. 2016. EASE Guidelines for Authors and Translators of Scientific Articles to be Published in English. European Science Editing 42(4):e1-e16. doi:10.20316/ESE.2016.42.e1

The latest edition and translations can be found at http://www.ease.org.uk/publications/author-guidelines
} 